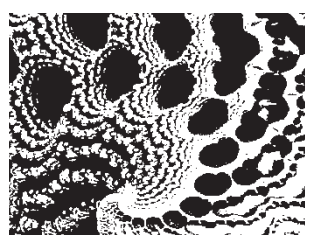

\title{
PORTRAYAL OF THE CROATIAN PROBATION SERVICE'S DEVELOPMENT IN PRINT MEDIA
}

Ines SUČIĆ

Institute of Social Sciences Ivo Pilar, Zagreb

UDK: 070:343.265(497.5)"2009/2013"

Izvorni znanstveni rad

Primljeno: 1. 12. 2015.

Supported by a grant (GrantID: OR2013. -1 1848) from the Foundation Open Society Institute in cooperation with the Scholarship programs of the Open Society Foundations.

Generally, research related to the media representation of probation is relatively rare, especially in jurisdictions without a long tradition of probation. The aims of this study were to investigate what themes emerged in constructing the public image of probation and who were probation's key promoters, and to analyse whether there was uniform presentation of probation in the media over time. The 390 newspaper articles related to probation that were published in national newspapers and magazines between 2009 and 2013 were analysed. The analysis showed that stories about probation were typically short, probation was typically not a main topic, and issues on probation were mainly superficially elaborated. Probation in Croatia has relatively low media visibility, but legislation, regulations, and expectations from probation emerged as main themes. Initially, reducing prison overcrowding and financial costs were the most frequently mentioned benefits of probation, but over time, attention shifted slightly towards focusing on the benefits of probationers' resocialisation and rehabilitation. The tone of the stories was generally positive or neutral, and politicians were the strongest advocates of the probation system. Media interest in probation fluctuated over the years, and probation has recently faced more criticism than before, most likely because of the many obstacles that it experienced in the course of becoming truly functional in practice.

Keywords: media analysis, probation, newspapers, supervision, offenders 


\section{MEDIA INFLUENCE ON THE PUBLIC'S PERCEPTION OF CRIME}

There is considerable public interest in all aspects of crime and justice, but public knowledge of crime and criminal justice is low (Roberts \& Hough, 2005). In making sense of crime, people rely on personal experiences, social networks and signs of disorder in the local community (Doyle, 2006). However, since most people have been neither victims of nor witnesses to crime, the media is typically the most common source of information about crime (McGreevy, 2013), and crime is considered a serious and newsworthy issue (Maruna \& King, 2004).

There is a long tradition of research on the influence of media on public discourse. Theories developed to understand and describe this effect (e.g. cultivation theory, social action theory / reception theory, agenda-setting theory / use and gratification theory, media dependence theory) predict, in essence, that exposure to media content affects the perceptions and attitudes of the audience. However, they differ in the estimated size of the effect that media exposure has on the audience, and in the estimated level of the audience's participation (active/passive) in receiving and interpreting the observed content. For example, cultivation theory predicts that prolonged media exposure creates the belief in a mean and scary world (Gerbner, 1988) and according to media dependence theory, audiences depend on media information to meet needs and reach goals, especially when social change and conflicts are high (Ball-Rokeach \& DeFluer, 1979).

Thus the mismatch between public attitudes towards crime and crime facts could be at least partially attributed to media representations of crime. The representation of crime in news media does not directly cause public beliefs and attitudes, but may have the potential to influence a range of criminal justice policies, as either a reflector of public opinion or an influencer of how policy is received by the public (e.g. through lobbying campaigns, headline stories) (McGreevy, 2013). The media usually tell us sensationalistic and distorted stories about crime. Their focus is mainly on violent and interpersonal offences. This way the media are playing upon public fears by overstating the danger of criminal victimisation, criticising the authorities for leniency, emphasising failure of rehabilitation, and calling for more and harsher punitive measures (Cheliotis, 2010; Roberts \& Hough, 2005). These misperceptions about crime trends and sentencing practices can lower levels of confidence in the criminal justice system (Mirrlees-Black, 2001). However, media portrayal can also increase visibility and public confidence in probation by providing substantive and reliable information about it ${ }^{1}$ (Allen, 2006) and consequently, raising knowledge about probation can incline people to favour rehabilitative approaches more and hold less punitive 
DRUŠ. ISTRAŽ. ZAGREB GOD. 25 (2016), BR. 4, STR. 481-502

SUČIĆ, I.: PORTRAYAL. attitudes (Butter, Hermanns, \& Menger, 2013). Thus, when trying to isolate and estimate the influence of media representation on the public, it is very important not to observe crime in the media as a unitary phenomenon but to take into account the diversity among news media organisations and formats, the content of the news, and audience heterogeneity (Doyle, 2006).

\section{MEDIA PORTRAYAL OF PROBATION SERVICES}

Probation is an area of the criminal justice system that has had limited media exposure (Phillips, 2014), and, not surprisingly, there is relatively little research done on it. The most common approach employed in research to date is content analysis of a selection of stories on probation that appear in printed media over a certain time period in order to examine how media representation of probation and public attitudes towards probation have changed over time (e.g. Maruna, 2007; Hayes, 2013; Maguire \& Carr 2013). Maruna's (2007) analysis showed that probation received positive media coverage until the 1970s, but that because of policy changes and increased political rhetoric around crime in recent years, probation has primarily been the subject of attention in the context of publicised failures. Similarly, Teague's (2002, p. 35) analysis of newspaper stories related to probation showed that community sentencing appears to be virtually invisible, and "hardly worth a serious discussion". An analysis by Hayes (2013) of 2000 newspaper articles published between 2003 and 2011 showed that community punishment is accepted by English newspapers as part of the criminal justice system, although there are conflicting opinions "as to what role these penalties should play within that system" (p. 34). Maguire and Carr's (2013) study of 542 newspaper articles over an 11-year period found that the majority of news stories about probation were either neutral or positive but noted a recent shift towards a more negative portrayal of probation that were a reflection of recent changes in the shape of penal-probation boundaries in Ireland.

The overall conclusion of previous research on the media portrayal of probation is that probation has not received much media attention particularly in comparison to other criminal justice institutions (e.g., prisons, the police, courts) (e.g. Maruna \& King, 2008; Phillips, 2014), that probation had a marginal position (Mason, 2006), and it was often portrayed as inferior to incarceration (Hayes, 2013). Probation's "image problem" (Bauwens \& Mair, 2012) could be partly a product of its ambiguous status as a combination of institutionalisation and community rehabilitation; questionable appropriateness and/ or legitimacy; the fact that probation does not provide the 
DRUŠ. ISTRAŽ. ZAGREB GOD. 25 (2016), BR. 4, STR. 481-502

SUČIĆ, I.: PORTRAYAL... same volume of information of interest to the public as other criminal justice topics and may not have reason to disseminate as much information to the public as e.g. the police; but it could also be related to its portrayal in the media (Maguire \& Carr, 2013; Roberts \& Hough, 2005). Probation needs to use the media to increase understanding and support of its work; as regards community sanctions, "ignorance is a fundamental problem" (McNeill, 2009) which may lead to the reemergence of popular punitive measures and to demands for more expressive and emotive forms of punishment (Bauwens \& Mair, 2012).

\section{PROBATION SERVICE IN CROATIA}

The Croatian Probation Service is a state service, financed by the government and under the jurisdiction of the Ministry of Justice. It provides interventions for adult offenders only. The first Probation Act in Croatia was enacted in 2009. It defines the purpose of probation work as protection of the community from an offender's offending; re-socialisation and re-integration of offenders in the community; and provision of support to victims of crime, their families and families of offenders (Špero, 2015, p. 134). The first probation office, out of 11, opened in 2011. In 2013, after a wider reform of criminal laws (sanctions and procedures), the professional Probation Service became fully functional (Špero, 2015). Since the Service started with work, the caseload has constantly been increasing. For example, in 2013 the Service received 3304 new cases, and 3618 new cases in 2014 (Špero, 2015).

Croatian probation officers are civil servants, performing probation tasks through the entire criminal process, from pretrial to post-release supervision. They supervise the enforcement of obligations ordered by the public prosecutor and have a role in prison sentence management through the enforcement of protective supervision during conditional release from prison. The main probation officers' activities and tasks include: delivering reports to the authorities, assessing the offenders' risk and/or suitability for imposed alternative sanctions; organising and supervising the enforcement of imposed sanctions; drafting a special individualised treatment programme for offenders.

\section{STUDY GOAL AND AIMS}

The main goal of this study was to investigate the public image of probation in Croatia to show what the public is allowed to know about the implementation of probation service, and its relations to other criminal justice institutions. The particular aims were: (1) to investigate what themes emerged in the 
DRUŠ. ISTRAŽ. ZAGREB GOD. 25 (2016), BR. 4 STR. 481-502

SUČIĆ, I.: PORTRAYAL... media's portrayal of probation and who were probation's key advocates, and (2) to analyse whether there was uniform presentation of probation in the media over time.

Since the establishment of probation and the enactment of new legislation related to probation and community sanctions was an important precondition for Croatia's joining the European Union (EU) in 2013 (Šimpraga, Maloić, \& Ricijaš, 2014), it was hypothesised: (a) that probation legislation, regulations and expectations will be the main topics in the media; (b) that at the beginning of Service development, more positive information about it will be presented in the media, especially by politicians; (c) that one of the common themes within the media's portrayal will be one of naivety about, for example, probation's potential for reducing the prison population; (d) that with time, issues regarding probation will become more politicised and criticised in the media due to obstacles the probation service experienced in becoming fully operational.

This topic is important to explore because there is no available information on how probation is viewed by the public or even by certain groups of the public (e.g. politicians) and because narratives presented in the media, especially about the issues that people have little direct experience with (such as probation), can either lower or boost confidence in the criminal justice system in general, and probation service in particular. Lower confidence can make the public become less inclined towards favouring rehabilitative approaches, and prone to undervaluing probation work, stigmatising and discriminating against offenders under supervision and making offenders' resocialisation even more difficult. New insights on media representation of probation service could also be used by the professionals and politicians to develop more efficient public relations strategies in the promotion of probation service, helping to avoid punitive attitudes and rigorous political responses as the dominant means of increasing public security.

\section{METHOD}

To provide the greatest possible representation of the topic on probation and increase the validity, all news articles from Croatia's national and local newspapers and magazines were included in the study (Macnamara, 2005). Newspaper articles were analysed since they are generally more accessible and lead to better recall than other news sources (e.g., TV, internet) (Furnham, Gunter, \& Green, 1990) and because mainstream newspapers have a more powerful influence on people's perceptions of public policies and political issues than does television news (e.g., Brians \& Wattenberg, 1996). News- 
DRUŠ. ISTRAŽ. ZAGREB GOD. 25 (2016), BR. 4, STR. 481-502

SUČIĆ, I.: PORTRAYAL... paper articles were located and collected using a press clipping agency's services because this approach provides fast and full access to all newspaper articles. The first year of this study, 2009, coincided with the year the Law on Probation was enacted and the Directorate for Criminal Law and Probation was established in Croatia. The end year of analysis, 2013, coincided with the wider reform of criminal laws in Croatia, and probation service becoming fully functional.

The unit of analysis was one newspaper article. Over the period in question, probation was mentioned in 533 national and local newspaper and magazine articles. Out of that, 390 news articles were included in the analysis, since the rest did not refer to the probation service or because they were identified as complete duplicates of other articles.

A primary researcher coded all sampled news articles. However, to ensure reliability of the study findings a sub-sample of $15 \%$ randomly selected news articles was coded by a second coder. Both coders were trained, and each coder coded the articles independently. Intercoder reliability proved to be satisfying.

To operationalise the patterns and themes that emerged throughout the articles, a structured closed-ended categorisation matrix was developed. The coding list consisted of the list of variables to be examined: general technical information about the news article, main article theme, different actors' experiences with and attitudes to probation, probation duties and instruments/technologies, expectations from probation, collaboration between probation service and other institutions. Each article was analysed based on the presence/absence of the categories in the coding list, assessed for overall content, themes and tone (positive, neutral-factual, negative). The frequencies of codes and classifications of information were calculated. After initial code identification, codes were matched up and collated with data extracts that demonstrate that code. The different codes were grouped into categories, and all the relevant coded data extracts within the identified categories were collated. Categories were then reviewed, refined and consequently organised into meaningful theme groups. The stories were repeatedly read in order to search for meanings and patterns, and the stories about probation were afterwards subsequently analysed using a thematic approach (Braun \& Clarke, 2006). Recurring themes and patterns of response that emerged were analysed and reported in the context of the research questions that allowed for exploring the meanings and emphases in stories about probation (Michaelson \& Griffin, 2005). 


\section{RESULTS AND DISCUSSION}

In Croatia over the 5-year period, most of the articles on probation were published in daily newspapers, articles about probation were generally short, probation was not generally the main story topic, probation-related headlines rarely appeared on newspaper cover pages, and issues on probation were mainly superficially discussed (Table 1).

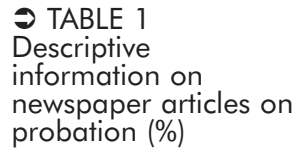

487

\begin{tabular}{llr}
\hline Variables & Categories within variables & $(\%)$ \\
\hline Type of the & daily newspapers & 82.5 \\
newspaper & weekly & 11.6 \\
& other & 3.6 \\
& monthly & 2.3 \\
Length of & 25\% of page or less & 27.8 \\
the article & > 1 page & 24.9 \\
& $75 \%$ of page & 14.9 \\
& $50 \%$ of page & 13.1 \\
& 30\% of page & 11.1 \\
& 1 page & 8.2 \\
Type of & short report & 42.4 \\
the article & news & 40.1 \\
& interview & 8.8 \\
& review & 7.5 \\
& column & 1.3 \\
Size of the title & medium & 40.3 \\
& big & 30.8 \\
& headline & 14.7 \\
Information & small & 13.4 \\
elaboration & no title & 0.8 \\
& sporadic topic & 55.4 \\
Probation topic & main topic & 38.5 \\
& equally important as other topic & 6.2 \\
& in-depth analysis & 19.0 \\
& & \\
& &
\end{tabular}

Altogether, it can be argued that probation in Croatia has relatively low media visibility. However, it is not known whether other criminal justice sanctions (e.g., prison sentences) are more or less present in the media than probation sentences because there has yet been no comparative analysis (Maguire \& Carr, 2013). Owing to different methodologies, traditions and time frames, it is difficult to compare probation's media visibility with existing analyses of media coverage on probation in other jurisdictions (e.g. Bauwens \& Mair, 2012). Moreover, because more serious and/or unusual offences, highly publicised cases, and scandals are most likely to earn 
DRUŠ. ISTRAŽ. ZAGREB GOD. 25 (2016), BR. 4, STR. 481-502

SUČIĆ, I.: PORTRAYAL...

D TABLE 2

Dominant themes in the newspaper articles on probation more media coverage (Greer \& Reiner, 2012), it is perhaps not detrimental for probation to have such low visibility.

In three-quarters of the newspaper articles, the term probation was not explained $(75.3 \%)$, which is particularly interesting given that the 2014 data showed that $87.3 \%$ of the Croatian public did not know what the term meant ${ }^{2}$ (Pilar's barometer of Croatian society, 2014). When existing, the definition of probation was mostly very short (e.g. system of supervised freedom, system of conditional freedom, or system of sanction execution out of prison). Also, only a quarter or less than a quarter of the news articles included a description of some personal experience with probation $(20.3 \%)$, collaboration of probation service with other institutions (25.6\%), and probation's mechanisms and instruments $(22.1 \%)$.

\begin{tabular}{lc} 
Themes & $\%$ out of 390 articles \\
\hline Legislation & 22.3 \\
Prediction for and expectations from probation & 19.7 \\
Experiences with probation & 16.9 \\
Probation officers' duties & 15.9 \\
Probation system's development & \\
(e.g. opening of new regional offices) & 13.1 \\
Employment in the probation service & 6.9 \\
Other topics & 2.8 \\
International examples & 1.8 \\
Victims' and witness' support & 0.5
\end{tabular}

As expected, probation legislation, regulations and expectations for the service were the two main topics in the media (Table 2) because between 2009 and 2013 Croatian probation service and probation policy was especially influenced by the politicisation of criminal justice policy as a result of necessary changes in Croatia's judiciary and laws that were imposed by the EU and its regulations in the process of Croatia's joining the EU. There were also personnel changes in the Ministry of Justice and Probation Service following parliamentary elections in 2011. In Croatia between 2009 and 2013, three Minister of Justice positions changed, three heads of the Probation Service positions changed, and two probation laws changed (Official Gazette, 153/2009; 143/2012). Even more, probation's official titles also changed three times over this 5year-period; "victims' and witnesses' support" was included and then excluded from the official title which clearly indicate the difficulties in articulating the public image of probation. In 2009 the official probation service title was Directorate for Probation; in 2010 it changed its name to the Directorate for Probation and Victims and Witnesses Support, and in 2012 to the Sector for Probation. Similarly, in the Republic of Ireland, dur- 
O TABLE 3 Expectations from probation ing the rebranding of probation in 2006, the word "welfare" was removed from its official title (Maguire \& Carr, 2013).

\begin{tabular}{lc}
\hline Expectation & \% of times mentioned in 390 articles \\
\hline Fewer people in prison & 45.9 \\
Fewer expenses & 21.0 \\
Other expectations & 16.7 \\
Resocialization & 12.8 \\
Less crime & 7.9 \\
More work places & 6.4 \\
Joining the EU & 6.4 \\
More human system & 5.9 \\
Better social security & 3.6 \\
More quality sanctions & 3.3 \\
System unload & 3.1 \\
Victims' support & 2.6 \\
Failure & 2.6 \\
More work for police & 1.8 \\
Easier job for judges & 1.3 \\
Offenders' monitoring & 1.3 \\
Greater expenses & 1.0 \\
Greater corruption & 0.8 \\
Keep family intact & 0.5 \\
Criminals will walk free & 0.5 \\
More work for POs & 0.5 \\
Less biased judges & 0.3 \\
Harder work for judges & 0.3 \\
\end{tabular}

Probation service establishment was accompanied with positive predictions and expectations in the media (Table 3). Prisons were obviously used as benchmarks in emphasising the Croatian probation service's benefits ${ }^{3}$ similarly to other jurisdictions, e.g. Ireland (Maguire \& Carr, 2013). Probation was glorified in the media as the best (and only) solution for problems facing the prison system (e.g., overcrowding, inhumanity, ineffectiveness, expense). As such, the probation rhetoric in almost half of the articles emerged as "fewer people in prisons" (Table 3). However, most of the analysed press failed to explore the underlying reasons for prison overcrowding or offer any deeper elaboration of penal policies, whether prisons or probation.

Probation was also presented as the solution for overcoming problems identified by European politicians such as human rights violations in prisons and out-of-date penal policies. The press intensively confronted the Croatian public with the fact that the prison system was not particularly effective in reducing recidivism; that poor prison conditions were harmful to health and safety; and that there was an urgent need for the humanitarian approach of probation (see Che- 
DRUŠ. ISTRAŽ. ZAGREB GOD. 25 (2016), BR. 4, STR. 481-502

SUČIĆ, I.: PORTRAYAL...

$\rightarrow$ TABLE 4

Actors whose experiences were described ung, 1988). Thus, probation was presented as not only aiming at public protection but also at the social inclusion of offenders, their resocialisation, rehabilitation and reintegration into society (Bauwens, 2011). Probation's transformative potential, humanitarian side of the penal and judicial system, and societal redemption was especially stressed.

The economic benefits of probation versus prison were also emphasised. The newspaper articles argued that probation would be less expensive (than prison), ${ }^{4}$ and produce more work places. These repeated claims of reduced expenses over the 5-year period surely safeguarded probation from criticism to a certain degree (see Fitzgibbon, 2012).

Among the negative predictions or expectations for probation, the most commonly mentioned was that offering probation in Croatia was merely a concession to the EU, that probation was a failure, and that it would produce even more work for police, and result in higher expenses (Table 3). In addition, probation was seen as a soft option, frequently equated with escaping or avoiding prison sentences and with freedom (see Hayes, 2013; Teague, 2002).

\begin{tabular}{lcc}
\hline Actor & Number of articles & $\%$ positive experience \\
\hline Offender & 37 & 87.2 \\
Probation officer & 12 & 50 \\
Firm/ NGO & 9 & 100 \\
Head of probation office & 6 & 50 \\
Judge & 6 & 66.7 \\
Offender's family & 3 & 100 \\
Police officer & 2 & 100 \\
Victim & 1 & 100 \\
Witness & 1 & 100 \\
Social worker & 1 & 100
\end{tabular}

Only one-fifth of the newspaper articles included a description of some aspect of personal experience with probation $(20.3 \%)$, and, as expected, due to the promotion of the new national service, the majority of the newspaper articles described positive experiences (Table 4). Offenders' experiences prevailed, while experiences of probation officers, and others involved in probation were rarely described. It was interesting that offenders' experiences were described mainly as positive, ${ }^{5}$ whereas this was the case for only $50 \%$ of the probation officers' experiences. Offenders' positive experiences mostly referred to their experiences with community work, such as: P. Č., sentenced to 730 hours of community work in a public kitchen, said, "...This is for me a type of redemption to society...They did not think I would try as hard as I did. I like it here, and I am even thinking of continuing volunteering here 
DRUŠ. ISTRAŽ. ZAGREB GOD. 25 (2016), BR. 4 STR. 481-502

SUČIĆ, I.: PORTRAYAL. in the public kitchen in the future from time to time, after I serve this sentence" (Ciglenečki, 2013, p. 5). However, in articles probationers were never referred to as "clients" but always as "offenders", and their offences were usually over-emphasised, adding to their dangerousness and dysfunctional personalities. Due to the dominance of "celebrity culture", (Greer, 2007) it was not surprising that Croatian journalists were eager to use politicians and celebrities who were sentenced to community work as (anti)models of probation on the newspaper cover pages (e.g. an ex-Minister of Agriculture sentenced to community work in public kitchen).

Probation officers' positive experiences were related to their satisfaction with the small numbers of probationers who breached orders, the very positive feedback from probationers who were sent to perform community work and from their employers, and the successful collaborations with state and local firms and organisations as well as NGOs in offering community work. For example, one offender's employer said: "He was extremely hard-working and a good worker. If I could, I would immediately offer him a permanent job. Whatever I gave him to do he would do it immediately, without complaining. He was really an ideal worker" (Kokoruš, 2013, p. 13). Negative probation officers' experiences were related to case-overload, shortages of probation officers and official cars, and the still insufficient numbers of contracts with firms to offer community work (e.g., Bašić, 2012; Rosić Zrinski, 2012).

\section{$\rightarrow$ TABLE 5 \\ Types of probation work and tasks mentioned}

$\%$ out of 266 articles

\begin{tabular}{lr}
\hline Community work & 51.5 \\
Protective supervision & 33.5 \\
Home imprisonment & 30.1 \\
Electronic monitoring & 30.1 \\
Risk assessment & 11.3 \\
Alcohol treatment & 6.8 \\
Victims' support & 4.9 \\
Conditional sentence & 4.1 \\
Opinions to the courts & 3.8 \\
Psychosocial treatment & 3.0 \\
Police curfew & 1.9 \\
Individual treatment plan & 1.9 \\
Drug testing & 1.5 \\
\hline
\end{tabular}

In almost a third of the newspaper articles $(31.8 \%)$ the probation work type was not mentioned. In the rest of the analysed articles the biggest attention was given to community work and protective supervision (Table 5) which corresponds to the high prevalence of community work orders that the Service currently supervises (2061 out of a total of 3000 
DRUŠ. ISTRAŽ. ZAGREB GOD. 25 (2016), BR. 4, STR. 481-502

SUČIĆ, I.: PORTRAYAL...

\section{O TABLE 6}

General attitude towards probation in news articles cases, Špero, 2015). Community work was positively presented in the media, particularly that which benefited the local community. Thus, community work was usually described as: an effective response to probationers' numerous problems; an opportunity for societal redemption; valuable work experience that probationers had rarely or never had before; having more positive effect than prison; increasing probationers dignity; and a sentence that did not isolate them from their communities and families. Almost a third of the analysed newspaper articles talked about home imprisonment and electronic bracelets even though these types of supervision do not exist in probation practice in Croatia. Thus, the probation service was frequently criticised for the never-fulfilled promise to introduce electronic bracelets: "changes in Ministers (of Justice) disenabled the use of electronic monitoring because no one wanted to make the decision about it; ...countries in the region adopted the model of electronic monitoring and used EU sources for it, and now there is no money left for electronic monitoring in the (Croatian) national budget" (Borovac \& Zrinjski, 2013, p. 25).

\begin{tabular}{lc}
\hline General tone & \% out of 390 articles \\
\hline Positive & 48.1 \\
Negative & 24.7 \\
Negative and positive & 10 \\
Neutral (only facts) & 7.5 \\
Cannot be decided & 0.7
\end{tabular}

Generally, news articles that referred to probation were considered positive in tone (Table 6), which is similar to the media's portrayal of probation in Ireland (Maguire \& Carr, 2013) but in contrast to the media's prevailing negative tone on probation in England (Fitzgibbon, 2012) and Belgium (Bauwens \& Mair, 2012). It was interesting that when probation in Croatia was the main topic of the article, the tone was deemed positive in most cases $(50.8 \%)$ but when probation was the secondary topic, the articles' tones were mostly deemed to be negative $(65.5 \%)$. Articles on the topics of probation predictions and expectations and probation system development were more often deemed positive. Positive portrayals of probation were related to its promotion at both the individual (probationer) and societal levels, but mostly in comparison with the negative aspects of the prison system. The opposite was found, however, for articles about laws and regulations and about experiences - these articles were more often categorised as negative in tone. The negative aspects of the newspaper coverage critiqued the probation system's inadequate functioning in practice and much less often referred to the 
DRUŠ. ISTRAŽ. ZAGREB GOD. 25 (2016), BR. 4 STR. 481-502

SUČIĆ, I.: PORTRAYAL... perceived leniency of probation orders. Some of the critiques were: "The probation office has only one secretary, phone and fax - probation is a dead letter" (Cmok, 2011, p. 16); "The practice of alternative sanctions is rare, so the law (on probation) is non-existent" (Jakubin, 2011, p. 3); "The purpose of the probation law is just to rebalance the national budget. Existing measures are already embedded in the law, so it is hypocrisy to offer the same measure under a different name" (Raić Knežević, 2009, p. 3). The course of probation's development in Croatia was also criticised by EU politicians because of the "inadequate storage of computers, software delays, shortages of official cars and probation officers, lack of space for probation officers, large numbers of unsolved cases, decreased probation sentencing because of case overload, the failure to introduce electronic monitoring, and the lack of furniture in probation offices caused by the failure of two public procurement tenders" (Raić Knežević, 2011, p. 4).

Only between one-fifth and one-quarter of the newspaper articles included a description of cooperation with other institutions and/or professionals $(25.6 \%)$, or supervision mechanisms and technologies $(22.1 \%)$. Typical descriptions included collaborations with local firms and NGOs with whom the Probation Service had signed contracts to provide community work for offenders. It was somewhat surprising that collaboration with other organisations and professionals (e.g. judges, police, local communities or social workers) was so scarcely mentioned in the media given that probation is not a closed system guided by autonomous values but tends to be developed or accomplished with other agencies and professionals. Especially in recent years, the emphasis on the importance of partnerships with other agencies and professionals has increased (e.g., Maloić \& Rajić, 2012; Rumgay, 2007).

Journalists, Ministers of Justice, politicians and professionals from the Probation Service and other politicians were the actors who most frequently expressed their opinions on different aspects of probation service ${ }^{6}$ (Table 7).

Journalists' attitudes towards probation were mainly positive (Table 7), especially in describing the development of the probation system, predictions and expectations, probation duties and officers' and offenders' experiences. But it is not clear whether this was the result of "probation workers cultivating local media contacts and succeeding in getting out good news" (Mawby \& Worrall, 2011, p. 18) - thereby promoting probation - or because they were members of teams of professional journalists and public relations professionals who were hired by the Ministry of Justice to publicly promote probation, or whether they were expressing their genuine professional opinions. Journalists' main critiques were pointed 
DRUŠ. ISTRAŽ. ZAGREB GOD. 25 (2016), BR. 4, STR. 481-502

SUČIĆ, I.: PORTRAYAL... towards the failure of developing a fully functional probation service over a period exceeding four years. They were especially critical of the announced introduction of electronic monitoring that had never started (and e.g., spent 1,2 million Euro from European funds on that 'project') and the lack of adequate resources' reassurance for making probation offices functional (e.g., insufficient number of official cars, probation officers, contracts with institutions that will enable community work).

\begin{tabular}{|c|c|c|c|c|c|c|}
\hline \multirow[b]{2}{*}{ Actors } & \multicolumn{6}{|c|}{ Attitude } \\
\hline & negative & $\begin{array}{r}\text { negative } \\
\text { and positive }\end{array}$ & positive & neutral & Total & $\%$ \\
\hline Journalists & 17 & 14 & 57 & 6 & 95 & 25.2 \\
\hline Ministers of Justice & 1 & 1 & 83 & 4 & 90 & 23.9 \\
\hline \multicolumn{7}{|l|}{ Probation Service } \\
\hline (Sector for Probation) & 2 & 0 & 40 & 2 & 44 & 11.7 \\
\hline Politicians & 14 & 1 & 13 & 1 & 29 & 7.7 \\
\hline Probation officers & 0 & 0 & 14 & 1 & 15 & 4 \\
\hline Offenders & 0 & 0 & 14 & 0 & 14 & 3.7 \\
\hline Lawyers & 6 & 1 & 6 & 0 & 13 & 3.4 \\
\hline Firms & 0 & 0 & 13 & 0 & 13 & 3.4 \\
\hline Others & 2 & 0 & 9 & 1 & 13 & 3.4 \\
\hline Judges & 1 & 4 & 6 & 1 & 12 & 3.2 \\
\hline Scientists & 0 & 0 & 12 & 0 & 12 & 3.2 \\
\hline NGO & 0 & 0 & 10 & 0 & 10 & 2.7 \\
\hline Prison managers & 2 & 2 & 4 & 0 & 9 & 2.4 \\
\hline Foreign politicians & 0 & 1 & 3 & 0 & 4 & 1.1 \\
\hline \multicolumn{7}{|l|}{ Other professionals (psychiatrists, } \\
\hline police officers, social workers) & 0 & 0 & 2 & 0 & 3 & 0.8 \\
\hline Government & 0 & 0 & 1 & 0 & 1 & 0.3 \\
\hline Total & 45 & 24 & 287 & 16 & 377 & 100 \\
\hline$\%$ & 11.9 & 6.4 & 76.1 & 4.2 & & \\
\hline
\end{tabular}

i TABLE 7

Main actors in newspaper articles and valence of their attitude towards probation
It is indicative that the main spokesmen for probation, aside from journalists, were not probation officers themselves but politicians. Ministers of Justice and politicians more frequently expressed opinions on probation laws and regulations and on predictions and expectations, while the Probation Service mainly discussed the development of the probation system. The attitudes expressed by the Ministers of Justice, the professionals from the Probation Service, probation officers and probationers towards different aspects of probation were almost all positive. Politicians expressed positive opinions on probation less frequently but their negative opinions on probation were mainly the result of the critique directed towards their political opponents who were supporting probation. For example, the Croatian Minister of the Interior voted against amendments of the Law on Probation 
(1) TABLE 8

General tone of the newspaper articles towards probation, and theme coverage per year in order "to protect police officers from getting more work" and another politician commented that a similar law on probation had already existed in Croatia for many years but was never put into practice due to a lack of financial means (F. L., 2012).

\begin{tabular}{lrrrrr}
\hline \multirow{2}{*}{ Article topic } & \multicolumn{2}{c}{} & & Year $(\%)$ \\
\cline { 2 - 6 } & 2009 & 2010 & 2011 & 2012 & 2013 \\
\hline Regulations and legislation & 46.6 & 17.3 & 11.7 & 46.7 & 8.4 \\
Expectations from probation & 66.3 & 42.7 & 41.2 & 27.2 & 25.4 \\
Employment & 5 & 21.3 & 11.7 & 6.5 & 0 \\
System development & 16.8 & 34.6 & 23.5 & 17.4 & 12.7 \\
Probation work tasks & 19.8 & 33.4 & 39.2 & 30.4 & 24 \\
Experiences & 5 & 2.7 & 17.6 & 27.2 & 59.1 \\
Total media coverage per year & 25.9 & 19.2 & 13.1 & 23.6 & 18.2 \\
Positive article tone & 32.6 & 20.9 & 9.1 & 15.0 & 22.5 \\
Negative article tone & 6.9 & 3.4 & 31 & 44.8 & 13.8 \\
\hline
\end{tabular}

There are some variations in the number of articles on probation over time, but overall coverage within the newspapers did not increase (Table 8). Over the period of five years, probation was a somewhat more frequent theme in 2009 and 2012. In 2011 and 2012, criticism of probation became somewhat more pronounced, most likely because supporters of the probation service were using the media to portray a positive image of the service in the beginning, but then disappointment, when it finally came to putting words into actions, produced considerable negative criticism of probation in the media in the later years. However, during 2013, when all probation offices became fully functional, there were also a number of government initiatives (e.g. distribution of promotion leaflets and brochures, presentations in the regional offices and in the media) aimed at increasing public knowledge on probation and providing more accurate and complete information about probation to the public (Ministry of Justice, 2014), and media portrayal of probation moved in the direction of story-telling about probationers' personal experiences. Thus it seemed that those efforts stopped the trend of negative reporting about the probation system.

Also, it was interesting to observe how the focus of the newspaper articles changed over time (see Table 8). While interest in writing about predictions and expectations significantly declined over years, interest in writing about personal experiences increased. Also the print media in Croatia were recently more focused on examples of successful collaboration between the probation service and local firms and NGOs in carrying out community work. Thus there were several 
DRUŠ. ISTRAŽ. ZAGREB GOD. 25 (2016), BR. 4, STR. 481-502

SUČIĆ, I.: PORTRAYAL... examples of probationers' success stories and how society, the local community and the individual benefited from the work the offenders had done. Such approaches help probation officers in their work becoming more understood by the general public and less ignored or distorted by the media (Mawby \& Worrall, 2011).

\section{STUDY LIMITATIONS}

Although this type of analysis has important advantages such as easy replication and its usefulness in documenting trends over time, several important limitations of this study should be acknowledged. In this study, the analysis was limited by the availability of newspaper articles, and due to time-consuming analysis it captured a small sample of the media content. Also, it should be noted that the observed trends in the media coverage of probation may not be an accurate reflection of reality (e.g. more interesting/publicised events receive more coverage than less interesting ones, and under the influence of the presence of other important (inter)national political and social events at the time). Also, this descriptive method may not reveal the underlying motives for the observed pattern in media coverage, and qualitative content analysis relies at least partially on researcher "readings" and interpretation of media texts (e.g. subjectivity of interpretation of some variables such as the tone of the article). Thus results collected in this study as well as suggested interpretations should be read with these limitations in mind. In order to increase the reliability and validity, as well as the generalisability of results in further studies, this method should be combined with other data sources and methods (e.g. interviews and observations), the data should be collected on larger samples over a longer time period. Also, media coverage of one issue should be compared to media coverage of similar issues in a particular medium and time-period. Due to greater influence of virtual information, it is recommended also to analyse the coverage of issues on probation on different internet web-sites, portals, and forums.

\section{CONCLUDING REMARKS}

The Croatian probation service has a low level of visibility in Croatian society (Pilar's barometer of Croatian society, 2014), and as probation services in other jurisdictions, relatively low visibility in the printed media (e.g. UK, Ireland, Belgium). Overall, there is an impression that Croatian media were not interested in probation and made inaccurate assumptions about the (higher) level of knowledge on probation held by the target audience. Probation themes were presented in rela- 
DRUŠ. ISTRAŽ. ZAGREB GOD. 25 (2016), BR. 4 STR. 481-502

SUČIĆ, I.: PORTRAYAL. tively brief forms and only superficially elaborated. Issues on probation were usually not the main topic in newspaper articles, and the media only tended to provide lengthy news or documentary coverage when problems or issues occurred that were not representative of routine probation work (see Mawby \& Worrall, 2011).

Legislations and regulations, and expectations from probation were the two main topics regarding probation that were usually promoted in the Croatian media by politicians and professionals from the Ministry of Justice and Probation Service. As expected, they were more dedicated to promoting than criticising the introduction of the probation service. Consequently, stories on probation were mostly positive or neutral in tone. Reduction of prison overcrowding, reduction of financial costs, lessening human rights' violations in prisons and benefits from offenders' resocialisation were the most frequently mentioned expectations from probation. In advocating the introduction of the service, the Croatian government and politicians also placed considerable emphasis on probation's rehabilitative role. Over the years, the focus on the potential benefits of probation shifted somewhat from "probation as a means of combating prison overcrowding" to "probation as a means of offenders' resocialisation". But, personal experiences, cooperation with other institutions and professionals, and mechanisms and technologies of supervision still remained covered in a small portion of the newspaper articles. Also, the trend of positive reporting on probation did not last for long, since issues concerning probation even over this five-year period became politicised and criticised due to the obstacles the service experienced in becoming fully operational.

For public attitudes to probation to become more positive and/or lasting and for the expansion and further development of Croatian probation, more initiatives and research that will raise public awareness and enhance visibility of the Probation Service are needed. The overall level of knowledge on probation should be raised in public by reporting on probation more frequently, defining probation more thoroughly, and giving more in-depth presentation of the goals and tasks of probation service and its interrelatedness to the criminal justice system. Probation should be promoted as a political response that aims to increase public security, minimise recidivism and restore public confidence in criminal justice. Rational appeals about benefits of various justice options should not be used in promoting probation to the public since it was clearly shown that: (a) there is difficulty in "selling" probation that captures a number of interventions against the singular, easily understood concept of imprisonment (Allen, 2006), and (b) the pub- 
DRUŠ. ISTRAŽ. ZAGREB GOD. 25 (2016), BR. 4, STR. 481-502

SUČIĆ, I.: PORTRAYAL... lic has been largely unconvinced by rational appeals and statistical argument in favour of probation based on the high costs of imprisonment or the growing numbers of incarcerated citizens (prison over-crowding) (Stead, MacFadyen, \& Hastings, 2002; Maruna \& King, 2004). Negative portrayal of probationers should also be avoided since this type of reporting increases exclusion and negative attitudes towards probation in general (Maruna \& King, 2008), and promotes a populist model of penal policy-making (Johnstone, 2000). Affirmative and personalised stories and a trend towards more affective reporting should be used instead for a more proactive promotion of the probation service ${ }^{7}$ (Maruna \& King, 2008). Newspaper articles should be more focused on personal experiences, transformed offenders, and offender redemption and redeemability in order for the probation service to take advantage of emotional appeal in promoting confidence in the criminal justice system, in engaging the public (Maruna, 2007; Maruna \& King, 2004), and focusing less on public protection (McCulloch \& McNeill, 2007). Also, through probation's links to social work and other institutions, the promotion of social inclusion, guidance, care and assistance offered to "offenders" is achieved (Bauwens, 2011; Maloić \& Rajić, 2012). The Croatian Probation Service, like other criminal justice services, should devote resources to research and media campaigns, and increase the use of media to disseminate the message that probation works (Doyle, 2006). Also, it should be the role of all employees in probation, as a reliable source of information, to take part in promoting probation by reporting accurately on community sentences and the role of probation, and by explaining successes, correcting inaccurate information and increasing the understanding of probation.

\section{NOTES}

${ }^{1}$ Although research about its true utility has been somewhat mixed (Maruna \& King, 2004).

2 In the 2012 survey, in Northern Ireland just over two-thirds of respondents (68\%) had heard of the PBNI (McGreevy, 2013).

3 Which was, again, expected because the only system the country was familiar with at the time was the prison system.

4 "According to professionals, one day in prison costs the state as much as three days on probation" (Rosić-Zrinski, 2012, p. 8).

5 Negative offenders' experiences were related to rare examples in which they had breached their probation orders (e.g., Raić Knežević, 2011).

${ }^{6}$ A total of 15 different categories of actors were identified in the analysed newspaper articles.

7 But not at the expense of the wishes of victims (McGreevy, 2013). 
Allen, R. (2006). What works in changing public attitudes to prison: Lessons from rethinking crime and punishment. In P. Mason (Ed.), Captured by the media: Prison discourse in popular culture (pp. 65-83). Cullompton: Willan.

Ball-Rokeach, S. J., \& DeFleur, M. L. (1979). A dependency model of mass-media effects. Communication Research, 3(1), 2-21.

Bašić, B. (2012, February 13). They should monitor offenders but do not have a single official car. Vjesnik, 12.

Bauwens, A., \& Mair, G. (2012). Probation work and the media. CEP Newsletter. Available at http://www.cep-probation.org/news/254/868/ probation-work-and-the-media

Bauwens, A. (2011). Organisational change, increasing managerialism and social work values in the Belgian Houses of Justice, Department of Offender Guidance. European Journal of Probation, 3(3), 15-30. https:/doi.org/10.1177/206622031100300302

Borovac, M., \& Zrinjski, M. (2013, January 5). Probation - electronic bracelets for prisoners' monitoring do still not exist even four years after announcement of their introduction in practice. Večernji list, 13.

Braun, V., \& Clarke, V. (2006). Using thematic analysis in psychology. Qualitative Research in Psychology, 3(2), 77-101. https:/doi.org/10.1191/ 1478088706qp063oa

Brians, C. L., \& Wattenberg, M. P. (1996). Campaign issue knowledge and salience: Comparing reception from TV commercials, TV news, and newspapers. American Journal of Political Science, 40(1), 172-193. https:/doi.org/10.2307/2111699

Butter, R., Hermanns, J., \& Menger, A. (2013). Simultaneous prediction of punitive and rehabilitation-oriented attitudes towards probation: An ecological approach. Probation Journal, 60(1), 24-39. https:/doi.org/10.1177/0264550512470190

Cheliotis, L. K. (2010). The ambivalent consequences of visibility: Crime and prisons in the mass media. Crime Media Culture, 6(2), 169-184. https:/doi.org/10.1177/1741659010378629

Cheung, C.-L. (1988). A critical analysis of probation service in Hong Kong. MSc Thesis, University of Hong Kong, China.

Ciglenečki, D. (2013, August 11). Redemption in public kitchen. Novi list, 13.

Cmok, V. (2011, July 29). Approved! 24 sata (večernje izdanje), 11.

Croatia. Law on probation. Official Gazette, 143/2012. Available at http://www.zakon.hr/z/234/Zakon-o-probaciji

Croatia. Law on probation. Official Gazette, 153/2009. Available at http://narodne-novine.nn.hr/clanci/sluzbeni/2009_12_153_3741.html

Doyle, A. (2006). How not to think about crime in the media. Canadian Journal of Criminology and Criminal Justice, 48(6), 867-885. https:/doi.org/10.3138/cjccj.48.6.867

Fitzgibbon, W. (2012). Probation and social work on trial. London: Palgrave Macmillan. 
DRUŠ. ISTRAŽ. ZAGREB GOD. 25 (2016), BR. 4, STR. 481-502

SUČIĆ, I.: PORTRAYAL...
F. L. (2012, November 22). Ranko Ostojić two times voted against. Slobodna Dalmacija, 12.

Furnham, A., Gunter, B., \& Green, A. (1990). Remembering science: The recall of factual information as a function of the presentation mode. Applied Cognitive Psychology, 4(3), 203-212. https:/doi.org/10.1002/acp. 2350040305

Gerbner, G. (1998). Cultivation analysis: An overview. Mass Communication and Society, 1(3-4), 175-194. https:/doi.org/10.1080/152054 36.1998.9677855

Greer, C., \& Reiner, R. (2012). Mediated mayhem: Media, crime, criminal justice. In M. Maguire, R. Morgan, \& R. Reiner (Eds.), The Oxford handbook of criminology, 5th edition (pp. 245-278). Oxford: Oxford University Press. https:/doi.org/10.1093/he/9780199590278.003.0009

Hayes, D. (2013). Reading between the lines. English newspaper representations of community punishment. European Journal of Probation, 5(3), 24-40. https:/doi.org/10.1177/206622031300500303

Jakubin, H. K. (2011, March 28). Arrested director of INA does not seek house detention instead of doing his time in Remetinec prison cell. Slobodna Dalmacija, 11.

Johnstone, J. (2000). Penal policy making: Elitist, populist or participatory? Punishment and Society, 2(2), 161-180. https:/doi.org/10.1177/ 14624740022227935

Kokoruš, I. (2013, July 25). Villain is chopping wood, adulterator is mowing grass, and smuggler is cleaning horse stables. Bjelovarac, 13. Macnamara, J. (2005). Media content analysis: Its uses, benefits and best practice methodology. Asia Pacific Public Relations Journal, 6(1), $1-34$.

Maguire, N., \& Carr, N. (2013). Changing shape and shifting boundaries - the media portrayal of probation in Ireland. European Journal of Probation, 5(3), 3-23. https:/doi.org/10.1177/206622031300500302

Maloić, S., \& Rajić, S. (2012). Potreba i značaj razvoja suradnje probacijskog sustava i sustava socijalne skrbi u RH (The need and importance of the development of cooperation between probation and the social care system in Croatia). Ljetopis socijalnog rada, 19(1), 29-52.

Maruna, S. (2007). The probation story: One hundred years of probation in the media. Vista Perspectives on Probation Criminal Justice and Civil Renewal, 11(2), 113-119.

Maruna, S., \& King, A. (2008). Selling the public on probation: Beyond the bib. Probation Journal, 55(4), 337-351. https:/doi.org/10.1177/ 0264550508096491

Maruna, S., \& King, A. (2004). Public opinion and community penalties. In A. Bottoms, S. Rex, \& G. Robinson (Eds.), Alternatives to prison: Options for an insecure society (pp. 83-112). Cullompton: Willan Publishing.

Mason, P. (2006). Lies, distortion and what doesn't work: Monitoring prison stories in the British media. Crime Media Culture, 2(3), 251-267. https:/doi.org/10.1177/1741659006069558

Mawby, R. C., \& Worrall, A. (2011). Probation workers and their occupational cultures. Available at http://www2.le.ac.uk/departments/criminology/ 
DRUŠ. ISTRAŽ. ZAGREB GOD. 25 (2016), BR. 4 STR. 481-502

SUČIĆ, I.: PORTRAYAL...
McCulloch, T., \& McNeill, F. (2007). Consumer society, commodification and offender management. Criminology and Criminal Justice, 7(3), 223-242. https:/doi.org/10.1177/1748895807078863

McGreevy, G. (2013). Probation and the role of public relations. Irish Probation Journal, 10, 90-103.

McNeill, F. (2009). Probation, rehabilitation and reparation. 2nd Annual Martin Tansey Memorial Lecture. Irish Probation Journal, 6, 5-22.

Michaelson, D., \& Griffin, T. L. (2005). A new model for media content analysis. Available at http://www.instituteforpr.org/wp-content/ uploads/MediaContentAnalysis.pdf

Mirrlees-Black, C. (2001). Confidence in the criminal justice system: Findings from the 2000 British crime survey. Home Office Research Findings No. 137. London: Home Office.

Phillips, J. (2014). Probation in the news: Transforming rehabilitation. British Journal of Community Justice, 12(1), 27-48.

Pilar's barometer of Croatian society (2014). Zagreb: Institut društvenih znanosti Ivo Pilar. Available at http://barometar.pilar.hr

Raić Knežević, A. (2009, June 29). Eyes wide shut (in Croatian). Novi List, 3.

Raić Knežević, A. (2011, December 4). They are supervising offenders on parole, but do not have cars. Glas Istre, 4.

Roberts, J. V., \& Hough, M. (2005). Understanding public attitudes to criminal justice. Maidenhead: Open University Press.

Rosić Zrinski, M. (2012, February 16). They enacted the law, established offices but forgot the equipment. Bjelovarac, 12.

Rumgay, J. (2007). Partnerships in probation. In L. Gelsthorpe, \& R. Morgan (Eds.), Handbook of probation (pp. 542-564). Collompton: Willan.

Stead, M., MacFadyen, L., \& Hastings, G. (2002). What do the public really feel about non-custodial penalties? London: Esmee Fairbairn Foundation.

Šimpraga, D., Maloić, S., \& Ricijaš, N. (2014). Croatia. In A. van Kalmthout, \& I. Durnescu (Eds.), Probation in Europe (pp. 1-32). Utrecht: CEP, Confederation of European Probation.

Špero, J. (2015). The sector for probation in the Republic of Croatia. Irish Probation Journal, 12, 131-140.

Teague, M. (2002). Public perceptions of probation. Criminal Justice Matters, 49(1), 34-35. https:/doi.org/10.1080/09627250208553499

\section{Prikaz razvoja hrvatske probacijske službe kroz objave u tiskanim medijima}

Ines SUČIĆ

Institut društvenih znanosti Ivo Pilar, Zagreb

Istraživanja načina prikaza probacije u medijima relativno su rijetka, posebno u zemljama u kojima probacija ne postoji od davnina. Ciljevi ovog istraživanja bili su ispitati koje teme dominiraju u konstrukciji slike probacije u javnosti, tko su glavni promotori probacije te je li se s vremenom promijenila 
DRUŠ. ISTRAŽ. ZAGREB GOD. 25 (2016), BR. 4, STR. 481-502

SUČIĆ, I.: PORTRAYAL... slika probacije u medijima. Analizirano je 390 članaka vezanih uz probaciju objavlienih u hrvatskim novinama i časopisima između 2009. i 2013. godine. Analiza je pokazala da su članci o probaciji najčešće kratki, da često probacija u niima nije glavna tema te da su teme vezane uz probaciju uglavnom površno prikazane. Pokazalo se da probacija u Hrvatskoj ima relativno slabu medijsku vidljivost, a zakoni, odredbe i očekivanja od probacije glavne su teme - kojima se pisalo. U početku su smanjenje prenapučenosti zatvora i smanjenje financijskih troškova bile najčešće spominjane prednosti probacije, ali s vremenom se pažnja nešto više usmierila na povlastice povezane s resocijalizacijom i rehabilitacijom osuđenika. Ton novinskih članaka o probaciii uglavnom je bio pozitivan ili neutralan, a političari su najgorljivije podupirali njezino uvođenje. Interes medija za probaciju varirao je tijekom vremena. Probacija se sada, u odnosu na prijašnje godine, više kritizira, vjerojatno zbog mnogih zapreka s kojima se probacijski sustav susreo prije no što je oživio u praksi.

Ključne riječi: analiza tiska, probacija, novine, nadzor, osuđenici

\section{(c) (1) $(9$}

Međunarodna licenca / International License:

Creative Commons Attribution-NonCommercial-NoDerivatives 4.0. 